\title{
Production Flow Optimization By Using Theory of Constraints
}

\author{
Hasianna Nopina Situmorang ${ }^{1}$, Nazaruddin Matondang ${ }^{2}$ \\ \{hasiannanopina@unimed.ac.id\} \\ Department of Mechanical Engineering, Faculty of Engineering, Universitas Negeri Medan ${ }^{1}$, \\ Department of Industrial Engineering, Faculty of Engineering, Universitas Sumatera Utara ${ }^{2}$ \\ hasiannanopina@unimed.ac.id
}

\begin{abstract}
The use of Theory of Constraints (ToC) is very necessary in overcoming problems in the production automation system in the industry. This research aims to overcome the rate of instant noodle production automatically in the factory. The study was conducted in a national company that produces instant noodles at Tanjung Morawa, North Sumatera, Indonesia. The experience of constraints of bottlenecks were observed at mixing station and cooking station caused by the different capacities between the work stations. This research uses the principle of continuous improvement. A linear programming method is used to optimize master production schedule (MPS) and determine the maximum throughput. The results showed that applying the theory of constraint in the flow rate can solve the problems in the production of instant noodle in the factory. The ToC eliminate the constraints on the bottleneck work stations so that the overall production flow can run effectively and efficiently. After optimal MPS results has been known, rough-cut capacity planning (RCCP) revisions are calculated and the results showed that the bottleneck work stations have become non-bottleneck work stations, and the maximum throughput has been achieved.
\end{abstract}

Keywords: bottleneck; theory of constraints; master production schedule;

\section{Introduction}

Product flow optimization is very important in the production process in industry, because it deals with the effectiveness and efficiency within a company [1,2]. It is known that production planning is very crucial in the success of the company, especially in the context of measuring the ability of a company to provide the products and its balance with the production process in the factory $[3,4]$. Thus, the compatibility between raw materials, production processes, and machine capacity must be carefully considered. If the production planning is not well regulated, the production process can cause bottlenecks in intermediate or final products [5]. Bottle necks occur when work stations have a smaller capacity than production requirements. One work station experiences a bottle neck if there is an increase in demand that exceeds the capacity of the machine, it will cause a delay in production or fulfillment of demand. Thus, the process of reducing bottlenecks must be carried out with a search starting from the materials, machines, and people who involve work in the factory. Several studies have been conducted to reduce the 
bottle neck for the effectiveness of the companies. The use of theory of constraints (ToC) is very well applied to explore parts of the production steps that experience obstacles in the production flow automatically $[6,7,8]$.

In this study, the observations on the production process have been carried out, namely in a company engaged in the manufacturing of products that produce machinery and human production works automatically, namely instant noodle production in Tanjung Morawa, Deli Serdang, North Sumatra, Indonesia. Briefly, the production process in the factory is carried out at six work stations, and it is known that not all production flows run smoothly from raw materials into the packaging. The observations results and the data analysis have shown that there were problems with slowing down in several work stations, namely the case of product buildup caused by differences in production capacity at one station with the previous work station, and ultimately becomes a bottleneck case. Sifting and mixing work stations always experience bottlenecks due to differences in work capacity which causes delays in the production process, and ultimately decreases in the number of products produced by the company. To overcome this problem efforts need to be made so that the working power of all stations can take place effectively.

The application of theory of constraints $(\mathrm{ToC})$ is very suitable to be used to overcome the problem of a production flow that runs automatically $[9,10]$. Several studies have been conducted using the theory of constraints to overcome bottleneck problems in a production process $[11,12]$. Thus, the strategy to overcome this bottleneck is appropriate to be used to solve the problem of instant noodle production which is carried out in this study. The ToC method is considered to be suitable for handling the bottleneck problems experienced by the company, because this method focuses attention on finding constraints that can slow down the production process, and help to maximize the amount of inventory and throughput $[13,14]$. Theory of constraints will be able to be used to trace and examine constraints to find out how those constraints affect the desired goals within the company. The purpose of this research is to overcome the problem of instant noodle production flow rate in companies that work automatically within the company by using theory of constraints.

\section{Materials and Methods}

\section{Research Procedures}

The research is classified as applied research through the stages of problem identification to the stage of taking corrective actions in an effort to solve the problems experienced by the company. Observation and data collection is done by observation. Retrieval of research data was carried out directly at of each work station as shown in Figure 1. Furthermore, research data are analyzed to ascertain the position of the bottleneck problem, and proceed with the application of theory of constraints to solve the problem. Continuous improvement will continue until the optimum production conditions are obtained so that the bottleneck problem of the production process can be overcome. The research step begins by observing the sequence of production processes and processing time of each work station, followed by calculating the production capacity at each work station. The next stage is to analyze the data aiming to find work stations experiencing bottlenecks, increasing capacity at the workstation section, and proceeding to recalculate the new capacity that has been successfully obtained. Production flow and capacity at work stations experiencing bottlenecks is further optimized by applying ToC. $\mathrm{ToC}$ application is also done to maximize throughput. 


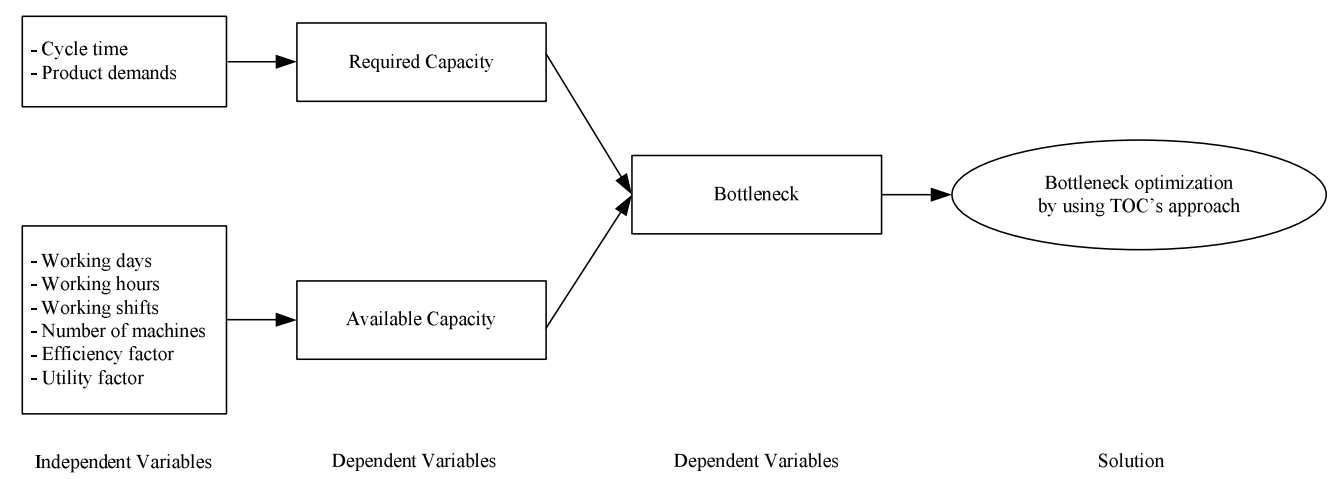

Fig 1. The conceptual framework on doing the study starting from problem identification to the stage of taking corrective actions to overcome the bottleneck problem of the production process.

\section{Results and Discussion}

\section{The Description of Production and Rating Factor Analysis}

In general, the process flow and production capacity of each work station (WS) for making instant noodles in the factory are shown in Figure 2. Each of the work station has a different production capacity and also resulted in various rating factors of production analysis.

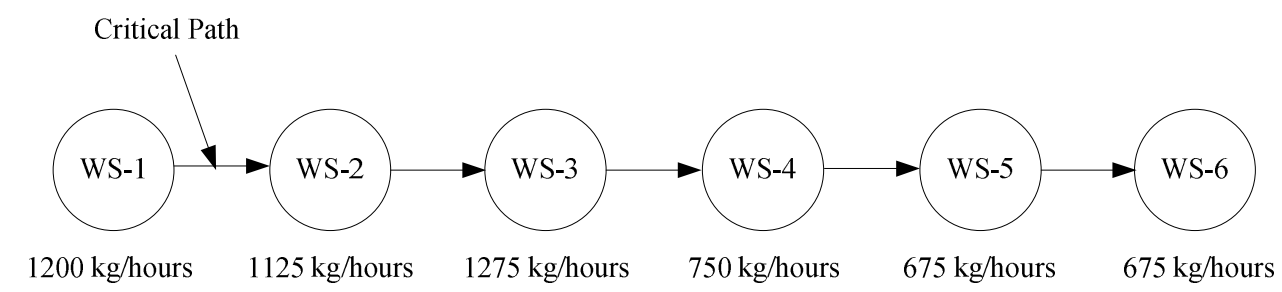

$$
\begin{array}{ll}
\text { Descriptions: } \\
\text { WS-1 } & \text { : Sieving Station } \\
\text { WS-2 } & \text { : Mixing Station } \\
\text { WS-3 } & \text { : Dough Forming Station } \\
\text { WS-4 } & \text { : Cooking Station } \\
\text { WS-5 } & \text { : Wrapping Station } \\
\text { WS-6 } & \text { : Packing Station }
\end{array}
$$

Fig. 2. Process flow and production capacities in each work station of the production of instant noodles

The results of observations have shown that the average percentage of the realization of the company's daily production plan is $90.1 \%$ and there is a buildup of $9.9 \%$ was found at the workstations. The small number of constraints in the form of bottlenecks will affect the overall company performance. Therefore, this obstacle must be resolved so that the company's 
performance can be improved. Improving company performance can be done by tightly scheduling the production process to optimize the work stations so that bottlenecks do not occur. In this case the standard time at each work station was calculated, the value of the rating factor of the observed operator was analyzed, and the allowance compensation given to the operator becomes a consideration in the management of instant noodle production. The results of the calculation of the standard time from manufacturing P-1, P-2, P-3 and P-4 products are summarized in Table 1.

Table 1. Standard time for each work station and product where RF $=$ Rating Factor, $\mathrm{A}=$ Allowance, and $\mathrm{ST}=$ Standard Time $(\mathrm{sec})$

\begin{tabular}{|c|c|c|c|c|c|c|c|c|c|c|c|c|}
\hline \multirow{2}{*}{$\begin{array}{c}\text { Work } \\
\text { Statio } \\
\mathrm{n} \\
\end{array}$} & \multicolumn{3}{|c|}{ Product-1 (P-1) } & \multicolumn{3}{|c|}{ Product-2 (P-2) } & \multicolumn{3}{|c|}{ Product-3 (P-3) } & \multicolumn{3}{|c|}{ Product-4 (P-3) } \\
\hline & $\mathrm{RF}$ & $\mathrm{A}$ & $\mathrm{ST}$ & $\mathrm{RF}$ & A & ST & $\mathrm{RF}$ & $\mathrm{A}$ & ST & $\mathrm{RF}$ & A & $\mathrm{ST}$ \\
\hline 1 & $\begin{array}{c}1,0 \\
9\end{array}$ & $\begin{array}{c}0,15 \\
0\end{array}$ & $\begin{array}{c}11,4 \\
1\end{array}$ & $\begin{array}{c}1,0 \\
9\end{array}$ & $\begin{array}{c}0,15 \\
0\end{array}$ & $\begin{array}{c}11,2 \\
9\end{array}$ & $\begin{array}{c}1,0 \\
9\end{array}$ & $\begin{array}{c}0,15 \\
0\end{array}$ & 9,09 & $\begin{array}{c}1,0 \\
9\end{array}$ & $\begin{array}{c}0,15 \\
0\end{array}$ & 9,10 \\
\hline 2 & $\begin{array}{c}1,0 \\
9\end{array}$ & $\begin{array}{c}0,13 \\
0\end{array}$ & $\begin{array}{c}23,1 \\
3\end{array}$ & $\begin{array}{c}1,0 \\
9\end{array}$ & $\begin{array}{c}0,13 \\
0\end{array}$ & $\begin{array}{c}22,8 \\
5\end{array}$ & $\begin{array}{c}1,0 \\
9\end{array}$ & $\begin{array}{c}0,13 \\
0\end{array}$ & $\begin{array}{c}18,2 \\
3\end{array}$ & $\begin{array}{c}1,0 \\
9\end{array}$ & $\begin{array}{c}0,13 \\
0\end{array}$ & $\begin{array}{c}18,2 \\
8\end{array}$ \\
\hline 3 & $\begin{array}{c}1,0 \\
9\end{array}$ & $\begin{array}{c}0,15 \\
0\end{array}$ & $\begin{array}{c}13,1 \\
8\end{array}$ & $\begin{array}{c}1,0 \\
9\end{array}$ & $\begin{array}{c}0,15 \\
0\end{array}$ & $\begin{array}{c}13,2 \\
0\end{array}$ & $\begin{array}{c}1,0 \\
9\end{array}$ & $\begin{array}{c}0,15 \\
0\end{array}$ & $\begin{array}{c}10,6 \\
3\end{array}$ & $\begin{array}{c}1,0 \\
9\end{array}$ & $\begin{array}{c}0,15 \\
0\end{array}$ & $\begin{array}{c}10,5 \\
5\end{array}$ \\
\hline 4 & $\begin{array}{c}1,1 \\
4\end{array}$ & $\begin{array}{c}0,18 \\
5\end{array}$ & $\begin{array}{c}22,5 \\
6\end{array}$ & $\begin{array}{c}1,1 \\
4\end{array}$ & $\begin{array}{c}0,18 \\
5\end{array}$ & $\begin{array}{c}22,5 \\
2\end{array}$ & $\begin{array}{c}1,1 \\
4\end{array}$ & $\begin{array}{c}0,18 \\
5\end{array}$ & $\begin{array}{c}18,2 \\
4\end{array}$ & $\begin{array}{c}1,1 \\
4\end{array}$ & $\begin{array}{c}0,18 \\
5\end{array}$ & $\begin{array}{c}18,1 \\
9\end{array}$ \\
\hline 5 & $\begin{array}{c}1,1 \\
7\end{array}$ & $\begin{array}{c}0,13 \\
5\end{array}$ & $\begin{array}{c}21,9 \\
3\end{array}$ & $\begin{array}{c}1,1 \\
7\end{array}$ & $\begin{array}{c}0,13 \\
5\end{array}$ & $\begin{array}{c}21,9 \\
1\end{array}$ & $\begin{array}{c}1,1 \\
7\end{array}$ & $\begin{array}{c}0,13 \\
5\end{array}$ & $\begin{array}{c}18,1 \\
0\end{array}$ & $\begin{array}{c}1,1 \\
7\end{array}$ & $\begin{array}{c}0,13 \\
5\end{array}$ & $\begin{array}{c}18,1 \\
6\end{array}$ \\
\hline 6 & $\begin{array}{c}1,1 \\
7\end{array}$ & $\begin{array}{c}0,13 \\
5\end{array}$ & $\begin{array}{c}12,0 \\
6\end{array}$ & $\begin{array}{c}1,1 \\
7\end{array}$ & $\begin{array}{c}0,13 \\
5\end{array}$ & $\begin{array}{c}12,6 \\
5\end{array}$ & $\begin{array}{c}1,1 \\
7\end{array}$ & $\begin{array}{c}0,13 \\
5\end{array}$ & $\begin{array}{c}10,3 \\
9\end{array}$ & $\begin{array}{c}1,1 \\
7\end{array}$ & $\begin{array}{c}0,13 \\
5\end{array}$ & $\begin{array}{c}10,5 \\
0\end{array}$ \\
\hline
\end{tabular}

\subsection{Product Demand Forecasting}

The product demand forecasting has been done on instant noodle products by using quantitative forecasting methods, and trend projection method with regression. Based on the data distribution, the forecasting method chosen for the production at workstation for P-1 and P-4 products are the cyclical and linear methods, and for the P-2 and P-3 products are used the cyclical and exponential methods. From the smallest SEE value obtained, it is decided to use the linear forecasting method ate the workstation for P-1 product, where the P-2 uses the exponential method, while the P-3 and P-4 are using the cyclical method. Forecasting results for the next twelve months can be shown in Table 2 . 
Table 2. The results of product demand forecasting in the next twelve months

\begin{tabular}{ccccc}
\hline $\mathrm{X}$ & \multicolumn{4}{c}{$\mathrm{Y}^{\prime}$ (boxes) } \\
\cline { 2 - 5 } (month) & P-1 & P-2 & P-3 & P-4 \\
\hline 13 & 53187 & 15067 & 18680 & 10130 \\
14 & 52242 & 13675 & 17446 & 10452 \\
15 & 51298 & 12410 & 18881 & 11362 \\
16 & 50353 & 11263 & 22600 & 12615 \\
17 & 49409 & 10222 & 27607 & 13876 \\
18 & 48464 & 9277 & 32560 & 14807 \\
19 & 47520 & 8419 & 36131 & 15158 \\
20 & 46575 & 7641 & 37365 & 14836 \\
21 & 45630 & 6935 & 35930 & 13926 \\
22 & 44686 & 6294 & 32211 & 12673 \\
23 & 43741 & 5712 & 27204 & 11412 \\
24 & 42797 & 5184 & 22251 & 10481 \\
\hline
\end{tabular}

\subsection{Master Production Schedule (MPS)}

The preparation of the master production schedule is carried out to plan the number of products to be produced over the next year. From the results, it is known that the master production schedule prepared for the four products is the same as the forecasting results. It is showed that the forecasting results from month 13 until 24 represented a master production schedule from January until December.

\subsection{Application of Theory of Constraints}

The application of theory of constraints (ToC) has been carried out to optimize the production of instant noodle products, and constraints on work stations have also been identified. From the calculation results, it is known that the variance obtained is the difference between the required capacity (CR) and the available capacity (CA). The load percentage calculations have also been carried out to find out which work stations are experiencing bottlenecks and non-bottlenecks. The variance that is negative and the percentage of loads that are below $100 \%$ indicate the category of non-bottleneck work stations, while the variance that is positive and the percentage of loads that are greater than $100 \%$ indicate the bottleneck work station category. Calculation of required capacity and available capacity is calculated using rough-cut capacity planning (RCCP) as summarized in Table 3. It is known that work stations 2 and 4 are work stations that have bottlenecks. With this result, improvements were made so that the bottleneck problem can be overcome. Several activities carried out such as (1) Decide how to exploit the constraint, (2) Subordinate everything else, (3) Elevation of the existing constraints, and (4) Go back to step 1 and avoid inertia. Each of which is explained briefly. 
Table 3. Results of Rough-Cut Capacity Planning

\begin{tabular}{|c|c|c|c|c|c|c|c|c|c|}
\hline \multirow[b]{2}{*}{ Month } & \multicolumn{3}{|c|}{ Workstation 1} & \multicolumn{3}{|c|}{ Workstation 2} & \multicolumn{3}{|c|}{ Workstation 3} \\
\hline & Variance & $\%$ load & $\begin{array}{c}\text { Des- } \\
\text { cription }\end{array}$ & Variance & $\%$ load & $\begin{array}{c}\text { Des- } \\
\text { cription }\end{array}$ & Variance & $\%$ load & $\begin{array}{c}\text { Des- } \\
\text { cription }\end{array}$ \\
\hline Jan & -696649 & 59,86 & NBN & 306752 & 117,1 & $\mathrm{BN}$ & -472421 & 71,84 & NBN \\
\hline Feb & -924279 & 52,07 & NBN & 37204 & 101,87 & $\mathrm{BN}$ & -763669 & 60,4 & NBN \\
\hline March & -928006 & 51,88 & NBN & 29259 & 101,47 & BN & -767954 & 60,18 & NBN \\
\hline Apr & -1002952 & 50,47 & NBN & -27741 & 98,67 & NBN & -839220 & 58,55 & NBN \\
\hline May & -679221 & 60,87 & NBN & 339875 & 118,95 & BN & -509608 & 70,64 & NBN \\
\hline June & -936444 & 53,75 & NBN & 104827 & 105,01 & BN & -761331 & 62,4 & NBN \\
\hline July & -728404 & 60,24 & NBN & 334175 & 117,65 & $\mathrm{BN}$ & -550592 & 69,95 & NBN \\
\hline Aug & -836105 & 56,64 & NBN & 211513 & 110,61 & $\mathrm{BN}$ & -660019 & 65,77 & NBN \\
\hline Sept & -1069028 & 49,6 & NBN & -68545 & 96,87 & NBN & -899492 & 57,6 & NBN \\
\hline Oct & -1228666 & 44,6 & NBN & -295365 & 87,11 & NBN & -1069570 & 51,77 & NBN \\
\hline Nov & -1013741 & 47,43 & NBN & -145941 & 92,68 & NBN & -866968 & 55,04 & NBN \\
\hline \multirow[t]{2}{*}{ Dec } & -1180390 & 41,71 & NBN & -386789 & 81,51 & NBN & -1045274 & 48,38 & NBN \\
\hline & \multicolumn{3}{|c|}{ Workstation 4} & \multicolumn{3}{|c|}{ Workstation 5} & \multicolumn{3}{|c|}{ Workstation 6} \\
\hline Month & Variance & $\%$ load & $\begin{array}{c}\text { Des- } \\
\text { cription }\end{array}$ & Variance & $\%$ load & $\begin{array}{c}\text { Des- } \\
\text { cription }\end{array}$ & Variance & $\%$ load & $\begin{array}{c}\text { Des- } \\
\text { cription }\end{array}$ \\
\hline Jan & 72917 & 103,66 & $\mathrm{BN}$ & -1883108 & 51,74 & NBN & -818360 & 58,05 & NBN \\
\hline Feb & -217654 & 90,16 & NBN & -2384339 & 45 & NBN & -1073566 & 50,47 & NBN \\
\hline March & -224711 & 89,84 & NBN & -2390258 & 44,86 & NBN & -1076488 & 50,34 & NBN \\
\hline Apr & -291861 & 87,44 & NBN & -2562805 & 43,7 & NBN & -1158977 & 49,08 & NBN \\
\hline May & 109545 & 105,5 & BN & -1842508 & 52,78 & NBN & -793127 & 59,34 & NBN \\
\hline June & -157658 & 93,21 & NBN & -2427661 & 46,67 & NBN & -1080381 & 52,53 & NBN \\
\hline July & 94496 & 104,5 & BN & -1962632 & 52,35 & NBN & -845071 & 58,96 & NBN \\
\hline Aug & -38319 & 98,27 & NBN & -2200674 & 49,24 & NBN & -965249 & 55,47 & NBN \\
\hline Sept & -339518 & 86,05 & NBN & -2712886 & 43,11 & NBN & -1226803 & 48,55 & NBN \\
\hline Oct & -576503 & 77,34 & NBN & -3054461 & 38,73 & NBN & -1406473 & 43,58 & NBN \\
\hline Nov & -393315 & 82,22 & NBN & -2551182 & 41,15 & NBN & -1165354 & 46,24 & NBN \\
\hline Dec & -644406 & 72,26 & NBN & -2906769 & 36,14 & NBN & -1353035 & 40,55 & NBN \\
\hline
\end{tabular}

$\mathrm{BN}=$ bottleneck, $\mathrm{NBN}=$ non-bottleneck

\section{(1) Decide how to exploit the constraint}

Optimization of the master production schedule is carried out using the theory of constraints so as to produce maximum throughput by utilizing the entire capacity of the work station bottleneck. To optimize the master production schedule in the application of the ToC linear programming methods are used. The target function is maximizing throughput. The constraint function in the equation formed is the capacity of the work station bottleneck and the number of requests for each product. The equations that can be formulated, for example for January, in WS-2 can be seen in Equation (1) - (7). 


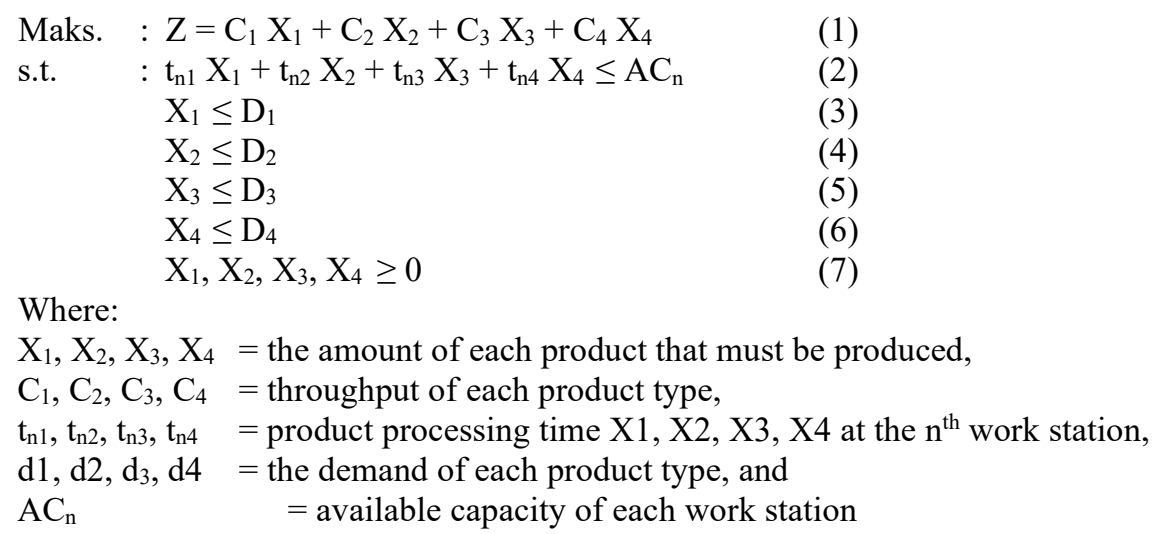

\section{(2) Subordinate everything else}

Optimization of the master production schedule at the work station experiencing bottlenecks, and the results of the calculation of the resulting throughput are summarized in Table 4.

Table 4. Optimal Production Master Schedule after aplication of theory of constraints

\begin{tabular}{|c|c|c|c|c|c|}
\hline \multirow{2}{*}{ Month } & \multicolumn{5}{|c|}{ Production (boxes) on Workstation 2} \\
\hline & $\mathrm{P}-1$ & P-2 & P-3 & P-1 & Throughput \\
\hline Jan & 53187 & 15067 & 12011 & 0 & 1971057000 \\
\hline Feb & 52241 & 13675 & 17446 & 8418 & 2121778000 \\
\hline March & 51298 & 12410 & 18881 & 9761 & 2103884000 \\
\hline May & 49409 & 10222 & 22877 & 0 & 1902928000 \\
\hline June & 48464 & 9277 & 32560 & 9072 & 2143781000 \\
\hline July & 47520 & 8419 & 29649 & 0 & 1908286000 \\
\hline Aug & 46575 & 7641 & 37365 & 3265 & 2033208000 \\
\hline \multirow{2}{*}{ Month } & \multicolumn{5}{|c|}{ Production (boxes) on Workstation 4} \\
\hline & $\mathrm{P}-1$ & $\mathrm{P}-2$ & P-3 & $\mathrm{P}-1$ & Throughput \\
\hline Jan & 53187 & 15067 & 18680 & 6121 & 2170635000 \\
\hline May & 49408 & 10222 & 27607 & 7855 & 2098917000 \\
\hline July & 47520 & 8419 & 36131 & 9963 & 2164479000 \\
\hline
\end{tabular}

\section{(3) Elevate the constraint}

Revised rough-cut capacity planning (RCCP) has been carried out to see whether the obstacles experienced by instant noodle production have been overcome. In this case all work stations are observed, that is, there are no more work stations experiencing bottlenecks. The results of the revised RCCP can be seen from the results summarized in Table 5. 
Table 5. RCCP Revision Results for Bottleneck Work Station

\begin{tabular}{clrrl}
\hline WS & Month & Variance & $\begin{array}{r}\text { Persentage of } \\
\text { Load (\%) }\end{array}$ & Description \\
\hline 2 & January & 0 & 100,00 & non-bottleneck \\
& February & 0 & 100,00 & non-bottleneck \\
& March & -7 & 100,00 & non-bottleneck \\
& May & -6 & 100,00 & non-bottleneck \\
& June & -9 & 100,00 & non-bottleneck \\
& July & -61080 & 96,77 & non-bottleneck \\
& August & -5 & 100,00 & non-bottleneck \\
4 & January & -6 & 100,00 & non-bottleneck \\
& May & 0 & 100,00 & non-bottleneck \\
& July & -2 & 100,00 & non-bottleneck \\
\hline
\end{tabular}

\section{(4) Go back to Step 1,}

The Evaluate if the bottleneck has been broken, and return to the beginning. All workstations have become non-bottleneck workstations, so that the constraints on the system have been completely overcome.

Bottleneck work stations, which are mixing work stations (WS-2) and cooking work stations (WA-4), are the weakest link in the production flow that experiences bottlenecks. At these two workstations, buildup occurs that limits production capacity and can hamper overall production flow. With the theory of constraints $(\mathrm{ToC})$, the bottleneck work station will be optimized so that it can smooth the overall production flow. Thus, at both bottleneck work stations there are constraints that must be removed to maximize the company's throughput $[15,16]$. The principle of continuous improvement theory of constraints (TOC) is applied to optimize capacity planning so there are no more bottleneck work stations. By using the linear programming method, the revised production master schedule is done by adjusting the capacity of the mixing and cooking work stations $[17,18]$.

Work in process (WIP) occurs because of an imbalance of capacity that occurs at work station facilities, causing buildup of semi-finished products or work facilities that are idle and cannot be used maximally [19]. With the optimization of the master production schedule, the company can minimize in the following cases: (1) Work in process (WIP), where the more optimal the amount of production done on the production floor, based on the optimal JIP results a reduction in the amount of production, the amount of product inventory half-finished will be lower, (2) The amount of waste (waste that does not add value and can inhibit activities in the production process) caused by the work in process at the bottleneck work station, namely the mixing and cooking work stations, can be minimized, and (3) The average completion time of the production process can be minimized by reducing waste which can cause poor production flow and material flow on the production floor. Thus, the application of the principle of theory of constraints can eliminate obstacles that cause bottlenecks and increase profit or output levels (throughput) [20]. 


\section{Conclusion}

The application of theory of constraints has been able to overcome the bolleneck experienced by instant noodle factories. The average value of the standard time required at each work station to complete the four products, namely in WS-1 is 10.22 seconds, WS-2 is 20.62 seconds, WS-3 is 11.89 seconds, WS-4 is 20.38 seconds, WS-5 is 20.03 seconds, and WS-6 is 11.40 seconds. The rough-cut capacity report results show that the mixing work stations (WS2) in January, February, March, May, June, July, and August and cooking work stations (WS4) in January, May, and July are bottleneck work stations. After optimizing the master production schedule by applying the principle of theory of constraints and using the linear programming method, the results show that WS-2 and WS-4 become non-bottleneck work stations and the constraints that cause bottlenecks can be removed. Based on the revised results of the master production schedule, a maximum throughput was obtained in January amounting to $\operatorname{Rp} 2,170,635,000.00$.

\section{References}

[1] van Dooren C. A Review of the Use of Linear Programming to Optimize Diets, Nutritiously, Economically and Environmentally. Frontiers in nutrition, 5, 48. doi:10.3389/fnut.2018.00048. (2018).

[2] De Groot, D.,H., Lischke, J., Muolo, R., Planqué, R., Bruggeman, F. J., \& Teusink, B. The common message of constraint-based optimization approaches: Overflow metabolism is caused by two growth-limiting constraints. Cold Spring Harbor: Cold Spring Harbor Laboratory Press. doi:http://dx.doi.org/10.1101/679019. (2019).

[3] Song, X., Peng, C., Li, G., He, Z., \& Wang, H. Optimization of operation parameters for helical flow cleanout with supercritical CO2 in horizontal wells using back-propagation artificial neural $\quad$ network. One, 11(6) doi:http://dx.doi.org/10.1371/journal.pone.0156358. (2016).

[4] Ju, F., Wen, Z. S., \& Li, Y. An optimization framework for wind farm design in complex terrain. Applied Sciences, 8(11) doi:http://dx.doi.org/10.3390/app8112053. (2018).

[5] Gundogar, E., Sari, M., \& Kokcam, A. H. Dynamic bottleneck elimination in mattress manufacturing line using theory of constraints. SpringerPlus, 5(1), 1-15. doi:http://dx.doi.org/10.1186/s40064-016-2947-1. (2016).

[6] Boyd L, Gupta M. Constraints management: what is the theory? Int J Oper Prod Manag 24(4):350-371. (2004).

[7] Gupta MC, Boyd LH. Theory of constraints: a theory for operations management. Int J Oper Prod Manag 28(10):991-1012. (2008).

[8] Orouji M. Theory of constraints: a state-of-art review. Accounting 2(1):45-52. doi:10.5267/j.ac.2015.12.004. (2016).

[9] Puche J, Ponte B, Costas J, Pino R, Fuente D. Systemic approach to supply chain management through the viable system model and the theory of constraints. Prod Plan Control 27(5):421-430. doi:10.1080/09537287.2015.1132349. (2016).

[10] Domijan, M., \& Rand, D. A. Using constraints and their value for optimization of large ODE systems. Journal of the Royal Society, Interface, 12(104), 20141303. doi:10.1098/rsif.2014.1303. (2015). 
[11] Biswan, Ali T. Studi Terapan Theory of Constraints Layanan Pemberitahuan Surat Paksa pada KPP Pratama Natar. Substansi, Volume 2 Nomor 2. (2018)

[12] Mabin, V., Yee, J., Babington, S., Caldwell, V., \& Moore, R. Using the Theory of Constraints to resolve long-standing resource and service issues in a large public hospital. Health systems (Basingstoke, England), 7(3), 230-249. doi:10.1080/20476965.2017.1403674. (2017)

[13] Panizzolo, Roberto. Theory of Constraints (TOC) Production and Manufacturing Performance. International Journal of Industrial Engineering and Management (IJIEM), Vol. 7 No 1, pp. 15-23. (2016)

[14] Tunggal, Amin Widjaja. Theory of Constraints (TOC) dan Throughput Accounting. Jakarta: Harvarindo. (2003)

[15] Henderson, K. A. A critique of constraints theory: A response. Journal of Leisure Research, 29(4), 453-457. doi:http://dx.doi.org/10.1080/00222216.1997.11949808. (1997)

[16] Petrides, D., Carmichael, D., Siletti, C., \& Koulouris, A. Biopharmaceutical process optimization with simulation and scheduling tools. Bioengineering, 1(4), 154-187. doi:http://dx.doi.org/10.3390/bioengineering1040154. (2014)

[17] Shao, X., ×, Z. X., Yu, X., \& Yang, J. A deadline constrained scheduling algorithm for cloud computing system based on the driver of dynamic essential path. PLoS One, 14(3) doi:http://dx.doi.org/10.1371/journal.pone.0213234. (2019)

[18] Andelkovic PM, Andelkovic A, Dasic P. The theory of constraints as a basis for production process improvement model. Актуальні проблеми економіки 10:251-260. (2013)

[19] Shih-Cheng, H., \& Shieh-Shing, L. Embedding ordinal optimization into Tree-Seed algorithm for solving the probabilistic constrained simulation optimization problems. Applied Sciences, 8(11) doi:http://dx.doi.org/10.3390/app8112153. (2018)

[20] Baesler F, Gatica J, Correa R. Simulation optimisation for operating room scheduling. Int J Simul Model (IJSIMM) 14(2):215-226. doi:10.2507/IJSIMM14(2)3.287. (2015) 